\title{
THE PRESENT STATUS OF WHITE GRUB PARASITES IN PUERTO RICO
}

\author{
By Georse N. Wolcotr, Entomologist, \\ Insular Experiment Station, Río Piedras, Puerto Rico
}

In less than ten years after its first introduction into Puerto Rico, the giant toad, Bufo marinus L., has changed the economic status of white grubs on the Island from that of a major pest to one of comparative rarity. The most obvious indication of such change is that fields of sugar cane on the South Coast, especially in the districts where grubs were formerly most abundant, ean now be successfully and profitably ratooned. When white grubs were abundant, such a procedure would have been impossible; now it is the rule. Formerly the roots of sugar cane were often so completely destroyed that the stalks had to be harvested months in advance of normal maturity; now they are so numerous that plowing and replanting are obviously unnecessary. To be sure, different varieties of cane are now being grown, and some other factors have been changed, but the one of importance is that white grubs are no longer present in sufficient numbers to cause appreciable injury to the cane roots. For this changed condition, the imported toad is almost entirely responsible.

Before the toad was introduced into Puerto Rico, careful studies on the natural enemies of white grubs indicated that, altho locally some of these native parasites were at times quite abundant, their effect on the white grub population as a whole was so slight as to be inappreciable. No definite records of abundance of the parasites at this earlier period are now available, so that an exact comparison with present conditions is impossible. Quite recently, the opportunity to judge of the present status of some of those parasites was furnished by the investigations of $\mathrm{Mr}$. Walter $\mathrm{F}$. Jepson, sent here by the sugar planters of Mauritius to collect white grub parasites for importation into that Island.

Two species of Tachinid flies, Cryptomeigenia aurifacies Walton and Eutrixoides jonesii Walton, were first discovered attacking May beetles at Añasco in 1912 by Messrs. Doige, Van Dine and Jones, (1) and were later collected in considerable abundance at Río Piedras by E. G. Smyth. During the spring and summer of 1933, Mr. Jepson collected thousands of May beetles at Añasco, Río Piedras and Cidra, 
from these recovering none of the latter species, and at Cidra only found approximately $1 \%$ of parasitism by the former.

The most extended investigations on the Scoliid wasp parasites of white grubs were conducted by Mr. H. D. Box at Aguirre (2), at a time when the toad had already been introduced, but before it had become sufficiently abundant to have produced an appreciable effect on the white grub population. Because of the scarcity of the Tachinid flies, Mr. Jepson concentrated his efforts on the Scoliid wasps, and the following paragraphs are taken from an informal report (3) which he presented to the writer shortly before his return to Mauritius.

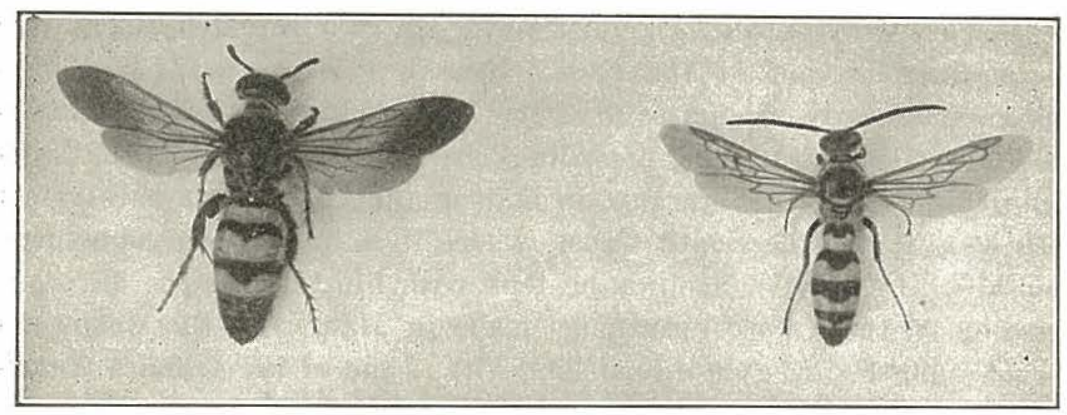

FIG. 5.-Female and male of Campsomeris trifasciata F. (after Box.)

"The species Campsomeris trifasciata F. was found by Box at only one spot near Aguirre. This locality was revisited and females found, during the present work, over eight years later. At no other locality on the South Coast has this species been found, but several females were seen at Isabela. Males have been seen, on Mitracarpus portoricensis, in a field at $\mathrm{Km}$. 33.4 along the San Juan-Arecibo road. In addition, a locality where twenty females may be obtained in a morning has been found in the hills, on Treasure Island Plantation, Cidra, in a field of abandoned pineapples, to the right of the Camp road 150 yards beyond the packing shed. The food plant is a pink straggling labiate; the males frequenting Mitracarpus."

"Elis xanthonotus Rohwer seems, with the foregoing species, to prefer the heavier soil types, and is, in addition, absent from the South Coast belt; its attachment to Mitracarpus as a food plant for both sexes may in this case be a determining factor. No specimens were collected at Santa Rita (Guánica), nor on the West Coast until Isabela was reached. Many individuals have been seen on the San Juan-Arecibo road, but the place of maximum abundance discovered is at Cidra, where the females are, on sunny mornings, the commonest Hymenoptera. Up to 150 individuals have been secured in a single morning's collecting. In an adjacent field, full of Mitracarpus, no trace of Elis could be found. The flight is spasmodic and tumbling, and the range evidently not great. The greatest success in rearing this species has been on the large grubs of Phyllophaga 
portoricensis or vandinei, though in the absence of these, oviposition and development takes place readily on 2 nd stage grubs, and the mature grubs of $P$. citri; the cocoons being naturally much smaller on the latter species. The time of development is longer at Cidra than that recorded by Box at Aguirre, the egg stage occupies over two days against 32 hours, and the larval period 8-10 days against 5 days in the South.',

"Campsomeris pyrura Rohwer, which was not found by Box at Aguirre, appears not uncommonly at Cidra. The males are quite abundant, both sexes frequenting Mitracarpus. No eggs have yet been obtained, and the species can have but little importance as a controlling agent, if, indeed, it be a parasite of Phyllophaga spp.",

It should be noted that these later observations by Jepson, mostly at Cidra, or along the North Coast, are hardly comparable to those of Box at Aguirre, and give little clue as to a changed status due to the introduction of the toad. Indeed, even concerning Campsomeris dorsata F., the parasite of the Dynastid beetle, Ligyrus tumulosus Burmeister, Jepson, recording observations made in the summer of 1933, only echoes Box in stating that it "is but rarely met with away from the South Coast, where it is by far the commonest Scoliid'. . Of all the Scoliids he took with him, it was the only one of which releases were eventually made in Mauritius, the wasps apparently possessing exceptional longevity, some of the females traveling 53 days and living over 40 days after arrival.

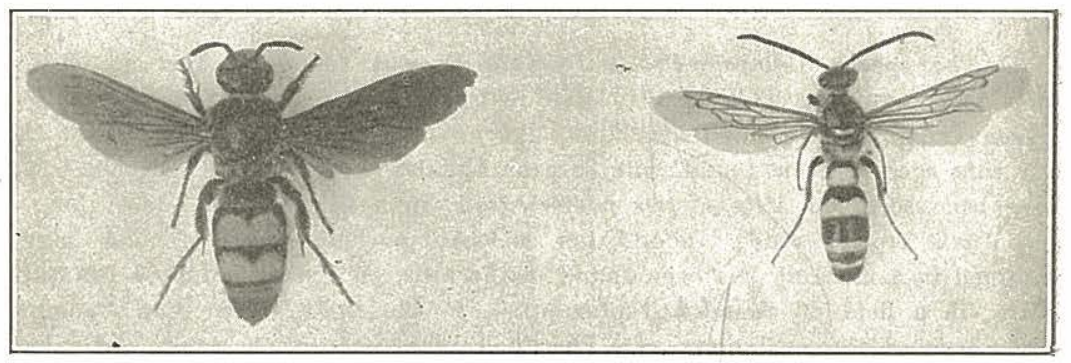

FIG. 6.-Female and male of Campsomeris dorsata F. (after Box.)

That Campsomeris dorsata was not an exclusively South Coast species was already known, for collection had been made at Maunabo, Trujillo Alto and Arecibo (4), but finding it in abundance on the North Coast was hardly to be anticipated. On June 7, 1933, Mr. Jepson and the writer noted several hundred males of this species resting in five or six clusters on low casuarina trees at the side of the School of Tropical Medicine, Puerta de Tierra, San Juan. So far as known, this is not only the first record of abundance on the 
North Coast, but also the first record of this swarming habit of the males, similar to that which has been so often observed of Elis haemorrhoidalis F. The School adjoins the U. S. Army barracks, and presumably the wasps had found there an abundance of host material, as Ligyrus grubs feed on decaying horse and mule manure as well as on cachaza and decaying cane stools and trash in the ground.

Apparently Campsomeris dorsata has experienced tremendous variations in abundance in Puerto Rico, for Gundlach in 1894 (5) records it as rare. The earliest economic record is in a letter written by $\mathrm{Mr}$. H. Bourne, at that time in charge of field experimental work for Guánica Central, from Santa Rita on June 20, 1913.

"While I was getting these grubs (of Ligyrus tumulosus Burm.) I found 28 cocoons of a wasp, very probably the black one with two reddish bands across the abdomen, because while digging, two flew out. This wasp is commonly seen in the callejones and cane fields. I also found one grub with a large size larva of a wasp attached to its body, one grub with a medium sized larva attached to it, and one with the egg of a wasp freshly laid on its body.",

In May, 1934, in the fields where he made these observations, only ten or twelve females were to be noted in a morning, mostly frequenting the flowers of the common bur marigold, Bidens pilosa L. Nothing comparable to the thousands inferred by Bourne and recorded by Box a few years previously was to be seen, even tho all conditions were apparently propitious: an abundance of cachaza in the field (for Ligyrus grubs) and an abundance of flowers for the wasps. It is evident that here the toad had so changed the balance of nature that Ligyrus had practically disappeared, and without a host, the wasp had also almost disappeared in this its previously most abundant habitat. The observations of Mrs. Dexter (6) on the food of the toad in cane fields indicate, indeed, that the wasps themselves are eaten: that is, both host and parasite are consumed by Bufo marinus.

Casual observations on the apparent abundance of this wasp may be grossly inaccurate, if made at the wrong time of day. On a bright sunny morning, no female wasps are to be found before 8 o'clock, and rarely are any to be seen until 9:00 A. M. From then until 11:00 A. M., they occur in increasing abundance, the males beginning to appear about 10:30 A. M. The appearance of the males, however, indicates the beginning of the end of the presence of the females on flowers, for while the males frequent the flowers during the hottest part of the day, the females are practically never present after 11:00 A. M. except when the early morning has been cloudy. No females at all appear during cloudy weather, and none are to be seen 
when a passing cloud temporarily obscures the sun. The common bur-marigold, Bidens pilosa, serves quite as well as a host for the females as do the flowers mentioned by Box, but the flower preferred by the females is the large yellow Calthrope, Tribulus cistoides L., present in considerable abundance in Puerto Rico only in San Juan and Puerta de Tierra. These flowers have a delightful perfume, suggestive of pansies, but they begin to close before noon, like the much smaller and paler yellow ones of the closely allied Kallstroemia maxima. Of this, Box states that "during its flowering season thousands of Hymenoptera are attracted by its delicate bloom; among the wasps, the Scoliid Dielis dorsato is the most frequent, and on sunny mornings thousands of the females of this species may be seen in most places where this plant occurs". A few wasps have been observed at Puerta de Tierra to feed only on this smaller yellow flower, but the great majority of them frequent only the larger and showier one. The early fading of these preferred hosts may have affected the feeding habits of the wasps to such an extent that they make no attempt to feed after these flowers are gone for the day.

During the summer of 1934, five times as many wasps were to be seen on the few patches of yellow Calthrope which encroaching building has left in existence on the wind-swept cliffs of Puerta de Tierra as at any point of the South Coast with a practically unlimited supply of flowers. Apparently the toad as a decisive factor has been practically eliminated in Puerta de Tierra by the impact of heavy urban street traffic, the few areas in which to hide during the day, and the scarcity of pools in which the immature stage might be passed. Thus, with an abundance of horse and mule manure available as host for the larva stage of Ligyrus tumulosus, the elimination of the chief predator (the toad) on these beetles has made possible the existence of their parasite, Campsomeris dorsata, in greater numbers than elsewhere in Puerto Rico.

\section{BIBLIOGRAPHY}

1. Van Dine, D. L.- "The Introduction of Parasites of May-Beetles into Porto Rico". Second Report Bd. Comm. Agr. P. R., 1912-13, pp. 36-48. San Juan, P. R. 1913.

2. Box, Harold E.- "Porto Rican Cane-Grubs and Their Natural Enemies"'. Jour. Dept. Agr. Puerto Rico, 9(4) : 291-356, fig. 21. October, 1925.

3. Jepson, W. F.- "Scoliid Wasps in Puerto Rico". p. 4. Unpublished MS, written Sept. 1933.

4. Wolcott, G. N. - "Insectae Portoricensis"'. Jour. Dept. Agr. Puerto Rico, 8(1) : 313, pl. 2. January, 1923. 
THE PRESENT STATUS OF WHITE GRUB PARASITES IN P. R. $\mathbf{4 4 1}$

5. Gundlach, Juan.-“"Fauna Puertorriqueña”, Ann. Soc. Española Hist. Nat., 16-22 : 347-658. May 31, 1887-Jan. 31, 1894.

6. Dexter, Raquel R.- "The Food Habits of the Imported Toad, Bufo marinus, in the Sugar Cane Sections of Porto Rico'. Bull. No. 74, International Society of Sugar Cane Technologists, p. 6, tab. 11, ref. 6. Fourth Congress, San Juan, March 1-16, 1932. 


\section{PLATE II.}

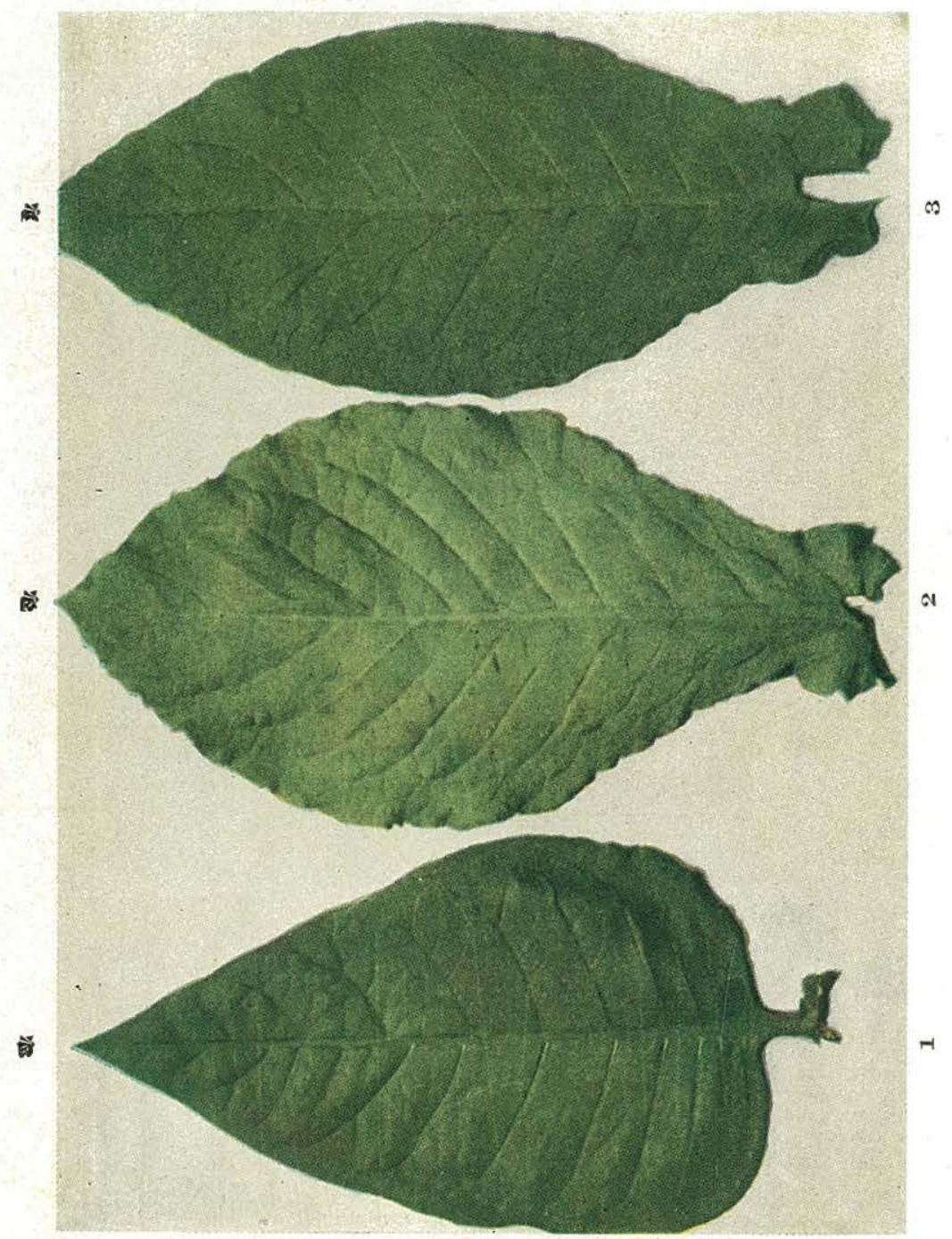




\section{EXPLANATION OF PLATE II}

FIGURE 1.-Ieaf of normal green Turkish tobacco.

FIGURE 2.-Leaf of No. 43, a yellowish-green "Ceniza", selection to show the yy character of Consolation tobacco.

FIGURE 3.--Leaf of "Ceniza"' or glaucous tobacco.

(The true characters have been poorly represented in the plate, the yellowish-green character is more uniformly yellow and the greens show too much of the yellow shade.) 


\section{NOTICE}

By Act of the Legislature of the Insular Government of Puerto Rico, the Insular Experiment Station has been transferred from the Department of Agriculture and Commerce of Puerto Rico to the University of Puerto Rico and the name of the Station changed to Agricultural Experiment Station of the College of Agriculture and Mechanic Arts of the University of Puerto Rico.

In accordance with this change;

The present Journal of Agriculture of the University of PUERTo Rico, starts with Volume XVIII, January 1934, and is a continuation of the Journal of the Department of Agriculture of PUERTo Rico, which suspended publication with the completion of Volume XVII, 1933.

Very truly,

Melville T. Cook, Editor. 